also seem that by the end of approximately 12 weeks onequarter $(27 \%)$ of women had responded to the placebo alone, that a further seventh had responded to imipramine (41\%), and a further fifth to E.C.T. (61\%).

We have not been able to identify any factors associated with the specific therapeutic responses; evaluation of demographic, social, and clinical characteristics revealed disappointingly little basis as reliable prognostic indicators. Thus there was no association between outcome as measured by final discharge from hospital and age, history of previous affective illness, and type of onset, previous duration, and clinical severity of the treated illness.

\section{Summary and Conclusions}

In 250 patients aged 40-69 years (81 men and 169 women) a comparison has been made between different treatments of depressive illness as specifically defined for the purpose of the trial. The treatments employed were E.C.T., imipramine, a monoamine oxidase inhibitor (phenelzine), and, for a short period of time, a placebo. These treatments were randomly allotted, and comparable groups thus set up and their progress assessed for six months. Many changes of treatment were made during the later stages of the trial period.

On both a short-term basis (after four weeks' treatment in hospital) and on a long-term basis (up to six months) it appears that E.C.T. and imipramine increased the frequency of recovery over and above the spontaneous rate shown by patients on the placebo. This drug, it appears, was specially effective in men and E.C.T. specially effective in women. For these patients, as defined by clinical condition and age, phenelzine revealed no advantage over the placebo in the treatment of men and gave even less favourable results than the placebo in women. Imipramine showed a slower action than E.C.T., but its use certainly reduced the total number of patients for whom E.C.T. was finally regarded.as necessary.
The Committee is greatly indebted to the 55 physicians (see below) who admitted patients to this trial and completed the records so carefully; to William R. Warner and Co. Ltd., and Geigy Pharmaceutical Company Ltd., who kindly supplied specially prepared indistinguishable tablets; to Dr. W. J. Martin and Miss B. Hafner for much of the statistical work; to Mrs. B. Grant, who traced many patients after their discharge; to Miss K. M. Blick for secretarial assistance ; and to Professor M. Hamilton, Dr. L. G. Kiloh, and Dr. M. W. Carney, who assisted the trial in Leeds and Newcastle.

Special recognition is made of the work of Dr. $\mathbf{R}$. H. Cawley, who co-ordinated the trial and provided invaluable assistance at every stage of the investigation.

The following were the participating hospitals and physicians:

Leeds Region.-Dr. D. E. Munro (Cliftan), Dr. E. A. M. Wood (Leeds General Infirmary), Dr. J. C. Little, Dr. J. M. Roberts (St. James), Professor Max Hamilton, Dr. A. Spellman, Dr. J. M. White (Stanley Royd), Dr. D. K. Bruce, Dr. J. E. Dessart, Dr. A. L. Smith (Storthes Hall).

London Region.-Dr. E. Roderic-Evans (Cane Hill), Dr. A. Mezey (Claybury), Dr. R. C. Gledhill (Goodmayes), Dr. J. D. Morrissey, Dr. J. Towers (Graylingwell), Dr. S. Benaim, Dr. E. H. Larkin (Halliwick), Dr. D. Rice, Dr. R. Maggs (Hellingly), Dr. S. Catterall, Dr. G. V. Stephenson (Hill End), Dr. B. A. J. C. Gregory (Horton), Dr. F. Letemendia, Dr. B. M. Mandelbrote (Littlemore), Dr. L. J. Clein, Dr. H. Conitzer (Long Grove), Dr. D. L. Davies, Dr. J. P. Dewsbery, Dr. J. G. Hamilton, Dr. E. H. Hare, Dr. W. Linford Rees, Dr. M. Shepherd (Maudsley and Bethlem Royal), Dr. A. N. Edwards, Dr. G. S. Gladstone (Napsbury), Dr. N. Farnan, Dr. M. J. Raymond (Netherne), Dr. C. M. Xavier (Oakwood), Dr. P. H. Mitchell (St. Augustine's), Dr. R. H. Wheeler (St. Francis), Dr. I. A. Horton, Dr. D. C. Watt (St. John's), Dr. I. C. Lodge-Patch, Dr. M. Markowe (Springfieid), Dr. C. F. Allfrey (Warley).

Newcastle Region.-Dr. G. A. Fitzpatrick, Dr. A. Gillis, Dr. C. F. Lascelles (Cherry Knowle), Dr. D. W. Kay, Dr. F. A. Whitlock (Newcastle General), Dr. L. G. Kiloh, Professor M. Roth (Royal Victoria Infirmary), Dr. J. Blackburn, Dr. D. D. Webster (St. Luke's), Dr. J. R. Roy (St. Nicholas), Dr. J. R. Hawkings (Winterton).

Applications for reprints should be made to Dr. M. Shepherd, Institute of Psychiatry, Maudsley Hospital, Denmark Hill, London S.E.5.

\title{
Auto-antibody Studies in Interstitial Pulmonary Fibrosis
}

\author{
MARGARET TURNER-WARWICK,* D.M., PH.D., M.R.C.P.; DEBORAH DONIACH, $†$ M.D., M.R.C.P.
}

Brit. med. F., 1965, 1, 886-891

Interstitial pulmonary fibrosis (“fibrosing alveolitis," Scadding, 1964) designates in terms of morbid anatomy a group of lung diseases which, although possibly not aetiologically homogeneous, is nevertheless characterized by similarity of microscopical, clinical, radiographic, and physiological features (see review by Livingstone et al., 1964).

Briefly, the condition presents most commonly in middle age and the sexes are affected equally. The presenting symptom is dyspnoea and the course is variably progressive but usually extends over years; the rapidly progressive illness described by Hamman and Rich (1944) is seen only occasionally. On examination of patients with moderately advanced disease central cyanosis is usually present, especially on exercise. Characteristic showers of fine rales are often heard and finger-clubbing is common. The radiographic changes vary from widespread "ground-glass" shadows to fine or coarse mottling, often denser at the bases, and as the disease advances

\footnotetext{
* The Institute of Diseases of the Chest, Brompton Hospital, London.
} t The Middlesex Hospital Medical School, London. small translucent cystic areas appear. The bronchographic appearances consist in condensation of the peripheral bronchioles with narrowing of the normal peripheral unfilled zone (Scadding, 1960). Physiological studies show small lung volumes, hyperventitation without airway obstruction, and diminution of carbon-monoxide uptake, indicating deficient gas-exchange. Hypoxia develops on exercise, and, as the disease progresses, is present also at rest, but hyperventilation maintains the carbon dioxide at low or normal levels. The compliance is reduced. The earliest pathological changes are thickening of the alveolar wall and an intra-alveolar exudate containing macrophages. With progressive fibrosis the normal alveolar architecture is destroyed and there is gross condensation of tissue leading to areas of scarring separated by cystic spaces. There is now general agreement with Scadding (1960) that the clinical pattern of the condition is often sufficiently characteristic to warrant diagnosis without resort to lung biopsy.

Although in many cases the lung changes occur in the absence of other diseases, the syndrome is well recognized in association with rheumatoid arthritis (Ellman and Ball, 1948), 
scleroderma (Hayman and Hunt, 1952), Sjögren's syndrome (Bunim, 1961 ; Tomasi et al., 1962), systemic lupus erythematosus (Israel, 1953), and dermatomyositis (Hyun et al., 1962), conditions in which autoimmunity is implicated. However, similar pathological features may be seen in cases of chronic pulmonary venous obstruction (Edwards and Burchell, 1951 ; Andrews, 1957), in prolonged interstitial pneumonias of infective origin, occasional cases of sarcoidosis (Bono et al., 1963), asbestosis, and coal-miner's pneumoconiosis (Heppleston, 1956). It seems possible that the study of immunological responses may provide information assisting in the classification of this heterogeneous group of lung disease.

Autoimmune diseases have been separated broadly into "organ-specific" and "non-organ-specific" categories (Hijmans et al., 1961 ; Mackay and Burnet, 1963). Organspecific disorders include thyroiditis, atrophic gastritis with and without pernicious anaemia, and Addison's disease resulting from adrenal atrophy. In these conditions there is destruction of specific cellular elements in the affected organ, invasion by lymphoid and plasma cells, and auto-antibodies which react predominantly with specific organs. In diseases of the second category, exemplified by systemic lupus erythematosus and allied connective-tissue disorders, the lesions are widely distributed, affecting many tissues, and the patient's serum contains antibodies which react with a variety of organs and animals. Between these two extremes there is an intermediate group of disorders in which specific organs show destructive lesions but where the antibody pattern is predominantly non-organspecific (Roitt and Doniach, 1965). Sjögren's syndrome, certain forms of chronic hepatitis and cirrhosis (Mackay and Wood, 1962), myasthenia gravis (van de Geld et al., 1963), and possibly rheumatoid arthritis fall into this category. In some of these disorders, especially Sjögren's syndrome and myasthenia, there is an increased incidence of thyroid-specific and gastric-specific antibodies as well as of antinuclear and rheumatoid factors.

In the present work the serum of 48 patients with diffuse interstitial pulmonary fibrosis has been examined for both categories of auto-antibodies, and the results have been correlated with clinical aspects of the disease.

\section{Materials and Methods}

Patients.-Forty-eight patients (26 males and 22 females) were studied. The mean age at the onset of chest symptoms was 53.4 years (males 54.5, females 52.4 years). The only criterion for omitting a patient from the series was a history of industrial exposure of known hazard, and no patient was excluded on account of rheumatoid arthritis or other disease. The present group included 14 patients ( 9 men and 5 women) fulfilling the criteria of the American Rheumatism Association (1959) for rheumatoid arthritis, but in three of these cases the joint manifestations had been acute, lasting two to four months, and had occurred two to five years before the present study was undertaken. Histological material from the lung was available in 19 patients and confirmed the diagnosis in every instance.

Controls.-Forty-eight subjects without obvious disease were selected from a larger group of controls previously tested by the same methods, and matched with the patients for age and sex. Rheumatod factor tests were not performed in the controls.

\section{Serological Investigations}

Tests for Rheumatoid Factors.-The slide latex F II test was performed on 1:20 dilution of inactivated serum by the method of Singer and Plotz (1956). The differential agglutination titre (D.A.T.) was carried out by a modified Rose-Waaler method (Rose et al., 1948), and the titre was expressed as a ratio of the agglutination observed with sensitized and unsensitized cells, in sera previously absorbed with uncoated sheep cells. Titres of $1: 16$ and over were regarded as positive.

Antinuclear Factors (A.N.F.).-These were detected by the double-layer immunofluorescent technique, using unfixed thyrotoxic thyroid and stomach mucosa as the substrates, and fluorescein conjugates of rabbit antihuman $\gamma$-globulin shown to react with both $7 \mathrm{~S}$ and $19 \mathrm{~S}$ antibodies. All sera were tested undiluted at room temperatures, and those giving positive reactions were retested in increasing dilutions. Sera negative by these tests were also tested using human buffy-coat smears as a substrate.

Non-organ-specific Complement Fixation.-This was performed with fresh rat-liver whole homogenates. The reaction detects a group of antibodies: some interact with soluble cytoplasmic proteins, while others are directed against particulate antigens present in a variety of organs. The later antibodies, besides fixing complement, give rise to coarsely granular cytoplasmic staining on sections of human thyroid and stomach as well as on rat kidney and other organs (Walker, et al., 1965). This non-organ-specific immunofluorescence can be distinguished from that of the organ-specific antibodies by the fact that all the cells in the sections are stained, including interstitial fibroblasts in the thyroid gland and chief cells and mucous cells in the stomach, while the organ-specific antibodies stain thyroid acinar epithelium and gastric parietal cells selectively and produce a more finely granular pattern.

Thyroid Antibodies.-Thyroglobulin antibodies were detected by the agglutination of formalized tanned red cells (T.R.C.) as supplied by Burroughs Wellcome. The immunofluorescent test was performed on fixed and unfixed thyrotoxic thyroid sections, for the detection of antibodies to the second colloidal antigen and to the microsomal antigens respectively. Sera giving cytoplasmic staining were further tested by the complement-fixation test (C.F.T.) to determine the titre of microsomal antibodies (see review by Doniach and Roitt, 1963).

Gastric Parietal-cell Antibodies were detected by immunofluorescence on unfixed gastric sections (Taylor et al., 1962) and by complement fixation using ficinized gastric mucosal homogenates.

\section{Preliminary Fluorescent Studies on Lung Tissue}

1. Circulating lung antibodies were looked for, using the fluorescent sandwich technique on the sera of seven interstitial pulmonary fibrosis patients, with fresh unfixed normal lung from a pneumonectomy specimen, and sections of a lung biopsy from a patient (Case 27) with interstitial pulmonary fibrosis.

2. Two lung biopsies (Cases 6 and 27) were examined for fixed antibodies with anti- $\gamma$ and anti- $\beta_{\mathrm{IC}}$ (complement) conjugates.

\section{Results}

Positive serological reactions of various types were found in 32 of the 48 patients studied, and details are listed in Table I.

\section{Non-organ-specific Auto-antibodies}

Rheumatoid Factors.-Differential agglutination titres of 1 in 16 and over were found in 23 of 48 patients (49\%). The titres were higher in the men, 6 out of 16 of whom had titres equal to or greater than $1: 128$, whereas only one out of seven women had a titre reaching this level. The slide latex test was positive in only 13 patients $(27 \%)$, all of whom also reacted with sensitized sheep cells. The correlation of these tests with the presence or absence of joint manifestations is shown in Table II. Twelve of the 14 patients with arthritis had a 
TABLE I.-Details of Cases

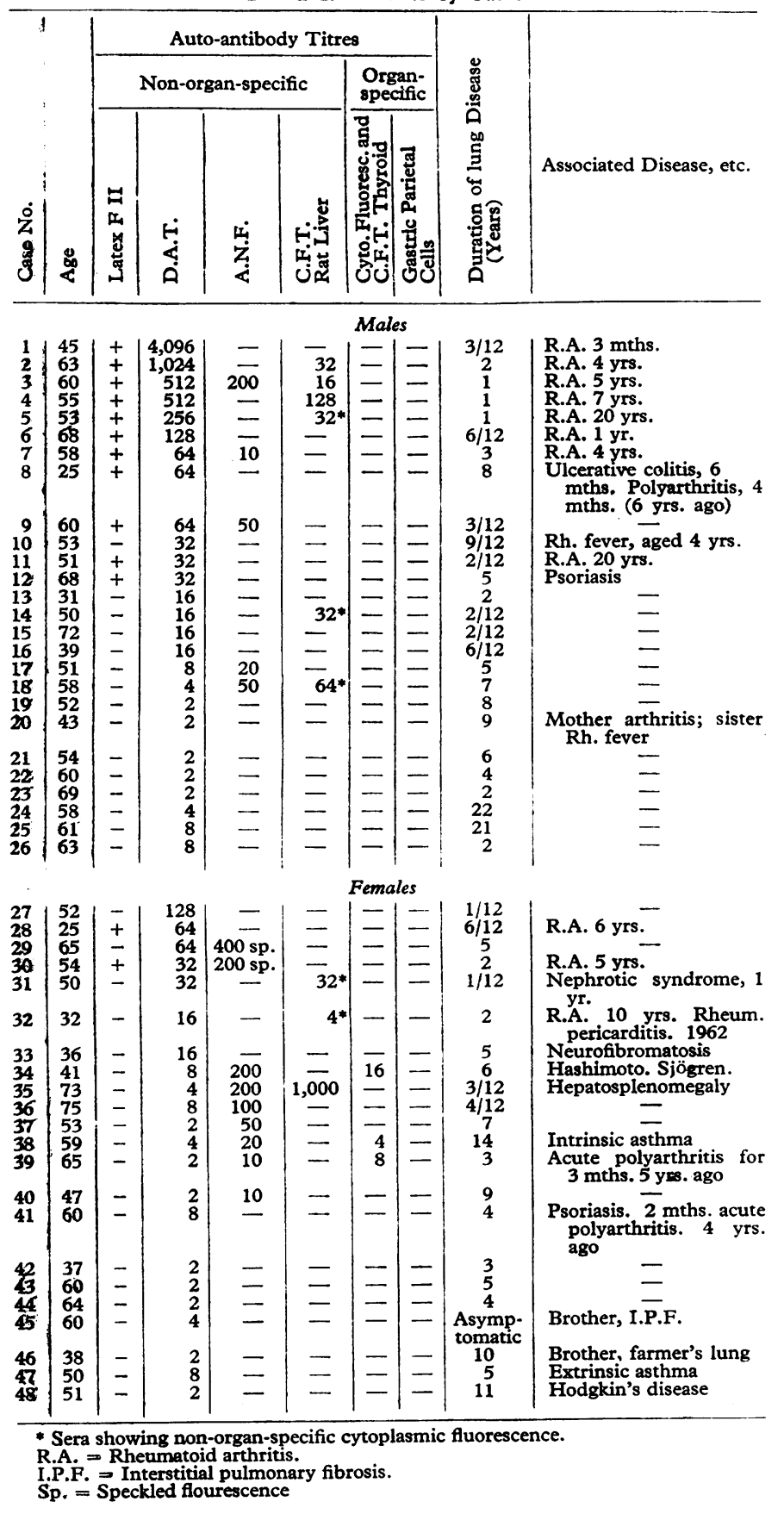

positive D.A.T., with titres ranging from $1: 16$ to $1: 4,096$. The two with negative D.A.T. were both women who had had only transient arthritic episodes several years before the tests. Of the 34 patients without arthritis, 11 had D.A.T. titres of $1: 16$ to $1: 128$, and it interesting to note that the latex test was negative in nine of them.

TABLE II.-Correlation of Rheumatoid Factors and the Presence of Arthritis in Patients with Interstitial Pulmonary Fibrosis

\begin{tabular}{|c|c|c|c|c|c|c|}
\hline \multicolumn{2}{|l|}{ Rheumatoid Factors } & \multicolumn{2}{|r|}{ Arthritis (14) } & \multicolumn{3}{|c|}{ No Arthritis (34) } \\
\hline $\begin{array}{l}\text { D.A.T. positive } \\
\text { Latex F II positive }\end{array}$. & $\begin{array}{l}\cdots \\
\therefore \\
\therefore\end{array}$ & $\begin{array}{r}12 \\
11 \\
2 \\
3\end{array}$ & $\begin{array}{l}(9 \mathrm{M} . \\
(9 \mathrm{M} . \\
(\mathrm{F} .) \\
(\mathrm{F} .)\end{array}$ & $\begin{array}{r}11 \\
2 \\
23 \\
32\end{array}$ & $\begin{array}{l}(7 \mathrm{M} . \\
(2 \mathrm{M}) \\
(10 \mathrm{M} . \\
(15 \mathrm{M} .\end{array}$ & $\begin{array}{l}4 \mathrm{~F} .) \\
13 \mathrm{~F} .) \\
17 \mathrm{~F} .)\end{array}$ \\
\hline
\end{tabular}

In Fig. 1 the distribution of D.A.T. titres has been charted for patients in this series, and divided into those with clinical arthritis (A) and those without joint involvement (B). Ball and Lawrence's (1961) figures for a sample of the general population have been included for comparison (C), and results for a rheumatoid population (Kellgren, personal communication, 1964) are shown in graph D. It can be seen that the distribution of titres in the patients with interstitial pulmonary fibrosis having polyarthritis is similar to that of the rheumatoid group, but that those of patients without arthritis lie between the normal and the rheumatoid groups and are significantly different from each of these by a non-parametric test of difference (Mr. P. M. Payne).

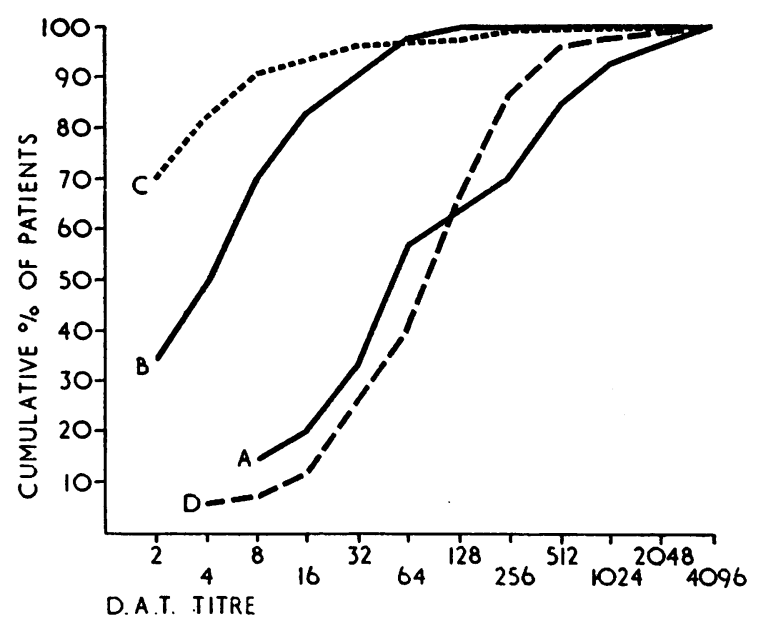

FIG. 1.-Distribution of D.A.T. titres in patients with pulmonary fibrosis compared with a sample of general population and with rheumatoid arthritis. For comparison the data have been charted according to Caplan et al. (1962).

Antinuclear Factors.-The A.N.F. test was positive in 14 $(28 \%)$ cases ( 5 males and 9 females). In five of them rheumatoid factors were also present. Diffuse nuclear staining was seen in 12 patients, speckled in 2, of whom one (Case 29) also had nucleolar antibodies. Of the nine patients with positive A.N.F. and no detectable rheumatoid factors, one had arthritis and one had non-haemolytic anaemia with hepatosplenomegaly (liver biopsy within normal limits). None of the patients had evidence of systemic lupus, and L.E.-cell tests were negative in every instance. In the matched control group the incidence of positive A.N.F. reactions was $4 \%$, and titres did not exceed $1: 20(\mathbf{P}<0.01)$.

Non-organ-specific Complement-fixing Antibodies.-Positive C.F.T. reactions with rat liver in titres up to $1: 1,000$ were found in nine (19\%) patients (6 males and 3 females), all of whom had rheumatoid factors and/or antinuclear factors. Five of these patients also gave non-organ-specific granular cytoplasmic fluorescence, suggesting a reaction with particulate antigens. Of the matched controls complement-fixing antibodies were found in one female at a titre of $1: 4(2 \%)$ $(\mathbf{P}=0.05)$.

\section{Organ-specific Auto-antibodies}

Thyroid.-Thyroglobulin antibodies, all of low titres (titre $1: 10$ in 4 cases, $1: 160$, and $1: 2,500$ ) were found in six patients and two controls (titre $1: 10$ and $1: 25$ ). Weak colloid fluorescence was obtained in eight patients and 10 controls. Cytoplasmic fluorescence was found in three female patients, all of whom were also positive by C.F.T. in titres of $1: 4,1: 8$, and $1: 16$. Of the controls, two had cytoplasmic fluorescence with negative C.F.T. The patient with the highest C.F.T. (Case 34) also had the highest T.R.C. titre. Her thyroid gland was slightly enlarged, firm, and irregular ; thyroid-function tests showed an impaired thyroid reserve; and a thyroid needle biopsy confirmed the presence of extensive lymphocytic thyroiditis with lymphoid germinal centres. This patient also had keratoconjunctivitis sicca and lymphoid infiltration of the portal tracts on liver biopsy, but had never had any joint 
involvement. The chest radiograph showed coarse mottling with some cyst formation, and the lung biopsy showed extensive fibrosis within the alveolar walls. (The earlier part of this patient's history has been reported by Scadding (1960).)

Gastric Parietal-cell Antibodies.-C.F.T. with gastric mucosa was negative in all the patients and none gave unequivocal fluorescence of the parietal cells. However, in five patients there was fluorescent staining of all the gastric cells, due to the presence of non-organ-specific cytoplasmic antibodies, and it is possible that weak reactions specific to parietal cells could have been missed. Of the matched controls, four gave weak parietal-cell fluorescence and no complementfixation reactions.

Experiments with Lung Tissue.-Application of sera from seven cases of interstitial pulmonary fibrosis, all of them with other serological evidence of autoimmunity, to lung tissue derived from the same disease and to normal lung sections produced no specific staining by immunofluorescence.

When the lung biopsies from two patients-having rheumatoid factor in one instance (Case 27, D.A.T. 1:128) and positive A.N.F. in the other (Case 9, A.N.F. titre 1:50) -were stained with fluorescent anti- $\gamma$ and anti- $\beta_{10}$ conjugates, no specific staining was produced in any of the lung structures, suggesting that there was no deposit of antigen-antibody complexes. However, numerous plasma cells were stained by the anti- $\gamma$ reagent.

\section{Correlation of Antibodies with Serum Proteins and Clinical Status}

Serum Proteins.-These were measured in 43 patients, total values ranging from 5.2 to $9 \mathrm{~g} . / 100 \mathrm{ml}$. (mean 6.9). Total serum-globulin values were available in 40 cases, and were abnormally high (more than $3.5 \mathrm{~g} . / 100 \mathrm{ml}$.) in 16 instances $(40 \%)$. The correlation of serum globulins with clinical arthritis, D.A.T., and A.N.F. is shown in Table III. Eight out of 13 patients with positive A.N.F. but only 7 out of 23 with positive D.A.T. had raised globulins. Clinical arthritis was present in 4 out of 16 patients with raised globulins. Electrophoretic strips were abnormal in 34 out of 43 patients tested and showed raised $\gamma$-globulins in $23, \alpha_{2}$-globulins in 16 , and $\beta$-globulins in 2. Quantitative measurements were not made.

TABLE III.-Serum Proteins and Presence of Positive D.A.T. and A.N.F. in 40 Patients with Interstitial Pulmonary Fibrosis

\begin{tabular}{|c|c|c|c|c|c|c|}
\hline \multicolumn{3}{|c|}{$\begin{array}{l}\text { Total Globulins } \\
\text { (G./100 ml.) }\end{array}$} & \multirow{2}{*}{$\begin{array}{c}\begin{array}{c}\text { No. of } \\
\text { Patients }\end{array} \\
24 \\
11 \\
5\end{array}$} & \multirow{2}{*}{$\begin{array}{c}\begin{array}{c}\text { Clinical } \\
\text { Arthritis }\end{array} \\
7 \\
3 \\
1\end{array}$} & \multirow{2}{*}{$\begin{array}{c}\text { Positive } \\
\text { D.A.T. }\end{array}$} & \multirow{2}{*}{$\begin{array}{c}\begin{array}{c}\text { Positive } \\
\text { A.N.F. }\end{array} \\
5 \\
4 \\
4\end{array}$} \\
\hline $\begin{array}{l}\text { Under } 3.5 \\
3.5-4 \\
\text { Over } 4\end{array}$ & & $\begin{array}{l}. \\
\because .\end{array}$ & & & & \\
\hline \multicolumn{3}{|c|}{ Total patients } & 40 & 11 & 23 & 13 \\
\hline
\end{tabular}

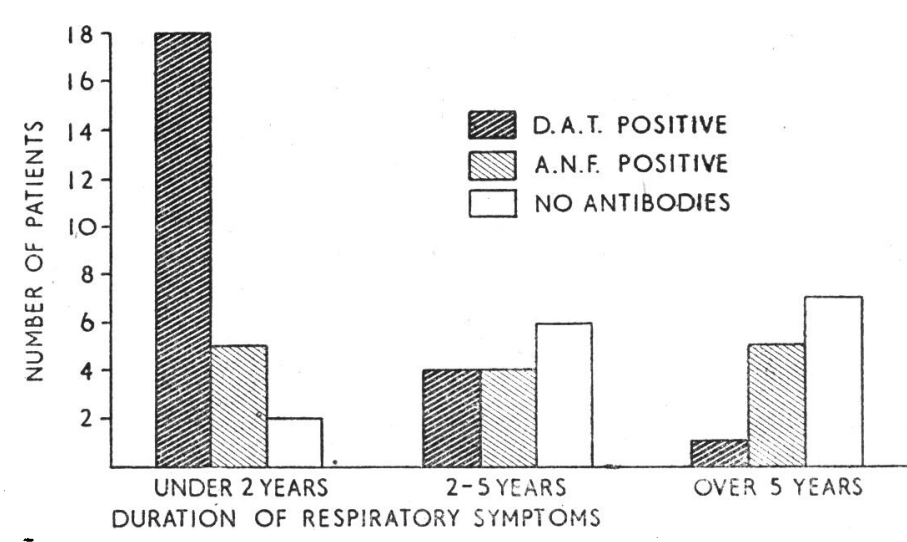
FIG. 2.-Correlation of the duration of respiratory symptoms with the
presence of rheumatoid factor and antinuclear antibodies.
Duration of Lung Symptoms and Presence of Tissue Antibodies.-The duration of lung symptoms is correlated with the presence of D.A.T. and A.N.F. in Fig. 2: A positive D.A.T. was seen more often in cases of short duration, but the presence of A.N.F. appears to be unrelated to the length of the respiratory history. There were more patients without detectable antibodies among the long-standing cases. In view of the correlation between the radiographic appearances and the maturity of the histological lesions (but not necessarily implying duration of disease) observed by Livingstone et al. (1964), the radiographs of 39 patients from this series have been graded according to those authors and the appearances related to the presence of antibodies (Table IV). The series studied is too small for complete analysis, but the figures suggest that in the group with advanced grade IV changes there may be more patients without detectable auto-antibodies.

TABLE IV.-Correlation Between the Grade of Radiographic Change and the Presence of A.N.F. and D.A.T.

\begin{tabular}{lc|c|c|c|c}
\hline & $\begin{array}{c}\text { Grade I } \\
\text { (Ground } \\
\text { Glass) }\end{array}$ & $\begin{array}{c}\text { Grade II } \\
\text { (Fine } \\
\text { (Mottling) }\end{array}$ & $\begin{array}{c}\text { Grade III } \\
\text { (Coarse } \\
\text { Mottling) }\end{array}$ & $\begin{array}{c}\text { Grade IV } \\
\text { (Cystic) }\end{array}$ \\
\hline No. of patients .. & $\because$ & 5 & 7 & 5 & 22 \\
D.A.T. positive & $\because$ & 4 & 5 & 2 & 8 \\
A.N.F. positive.. & $\because$. & 0 & 0 & 2 & 3 \\
No antibodies.. & $\because$ & 1 & 2 & 1 & 11 \\
\hline
\end{tabular}

\section{Discussion}

The association of idiopathic pulmonary fibrosis with connective-tissue disorders suggested a possible relation to autoimmunity (Forbes, 1958 ; Scadding, 1960 ; Hennes et al., 1961 ; Tomasi et al., 1962 ; Livingstone et al., 1964). At least three types of pulmonary disease can be distinguished in patients with rheumatism (excluding Caplan's syndrome, which is discussed below). The lung changes found in acute rheumatic fever are more probably related to the altered haemodynamics of rheumatic carditis, and should be distinguished from the pulmonary lesions of classical rheumatoid arthritis, which occur in two forms. Rarely, true rheumatoid nodules, histologically identical with those of the subcutaneous tissues, appear in the lung (Price and Skelton, 1956). Less infrequently diffuse interstitial pulmonary fibrosis is seen in patients with rheumatoid arthritis (Ellman and Ball, 1948), and this may either precede or follow the joint manifestations.

Franklin et al. (1959) reported the presence of rheumatoid factors in seven out of nine patients with interstitial pulmonary fibrosis, the majority of whom had joint symptoms. More recently Tomasi et al. (1962) have emphasized the frequency of pulmonary involvement in rheumatoid patients having high titres of rheumatoid factors. The latter authors also pointed out that rheumatoid factors may be found in patients with lung lesions in the absence of joint manifestations, and this is of particular interest, since the microscopical appearances in the lungs may be identical in cases with and without arthritis. Tomasi et al. obtained positive latex F II and D.A.T. reactions in 11 out of 18 such patients. Of the 34 patients without joint involvement studied by us, 11 had positive D.A.T., but, interestingly, only two reacted in the latex test. This contrasts with other non-arthritic diseases in which rheumatoid factors when present can be detected more often by the latex test (Dresner and Trombly, 1959).

Discrepancies between the D.A.T. (in which antibodies react against rabbit globulin) and the latex test (which uses human $\gamma$-globulin) are due to the different specificities of these distinct rheumatoid factors. Rabbits exposed to silica particles develop a rheumatoid factor which also reacts better with heterologous (human) globulins, and this might suggest that the initiating stimulus for this type of anti- $\gamma$-globulin antibody is an external one (Pernis et al., 1963). However, in the experiments of Milgrom and Witebsky (1960), animals immunized with 
homologous $\gamma$-globulin also produced antibodies reacting preferentially with human globulins. Therefore the results obtained in patients with interstitial pulmonary fibrosis do not necessarily imply that the disease is caused by an external agent.

In 1953 Caplan described a condition in miners with rheumatoid arthritis that was characterized by a coarsely nodular radiographic appearance in the lungs. An anarthritic form of this syndrome has been described recently (Caplan et al., 1962), showing two immunological similarities with our group of patients having no joint symptoms. The distribution of the D.A.T. titres is similar and falls midway between that of patients with rheumatoid arthritis and normal controls. The latex test in anarthritic Caplan's syndrome is also less often positive than the D.A.T. These common features suggest that $\lambda$ similar type of anti- $\gamma$-globulin antibody may be produced in the two conditions. This idea is further supported by the finding of occasional cases of Caplan's syndrome having atypical radiographic features which more closely resemble those of non-industrial interstitial pulmonary fibrosis.

There have been no reports of systematic A.N.F. studies in patients with interstitial fibrosis in spite of the evidence relating some of these cases to rheumatoid disease, and of the known overlap between rheumatoid arthritis and lupus erythematosus. In the present group $28 \%$ had detectable antinuclear antibodies and they were found more commonly in women. Only four patients with A.N.F. had rheumatoid arthritis, although two others had a positive D.A.T. The numbers are small, but it appears that the incidence of A.N.F. in rheumatoid patients with lung involvement does not exceed that obtained with our methods in an unselected rheumatoid arthritis population. Of eight A.N.F.-positive patients having neither arthritis nor rheumatoid factor, two had suggestive evidence of autoimmune involvement in other systems, but in six the lung was the only organ clinically involved. The lower A.N.F. titres and the negative L.E.-cell tests clearly separate the pulmonary disease from systemic lupus but bring it into line with related connective-tissue disorders belonging to the same category of non-organ-specific immunological disturbances. As mentioned already, Sjögren's syndrome has been reported in association with interstitial pulmonary fibrosis in a number of cases (Tomasi et al., 1962) and was seen in one of our patients. Two of our cases had hepatomegaly, and the liver biopsy showed mononuclear-cell infiltration of the portal tracts in one. Heppleston (1956) and Forbes (1958) also recognized the association of " honeycomb lung" with hepatitis. Twentysix sera with negative A.N.F. on tissue sections also failed to react with white-blood-cell nuclei and therefore did not contain leucocyte-specific A.N.F. which has been found in occasional cases of rheumatoid arthritis and Felty's syndrome (Faber et al. 1964).

The increased incidence of non-organ-specific complementfixing antibodies is further evidence of the relation with the connective-tissue disorders, and also relates the pulmonary disease to progressive active hepatitis and primary biliary cirrhosis. In our pulmonary fibrosis group antibodies to both the "soluble" and "particulate" types of cytoplasmic constituents were found. Coarsely granular fluorescence was seen in half the cases with positive liver C.F.T., and similar results were obtained in progressive hepatitis or so-called “juvenile cirrhosis." This granular fluorescence was not found in patients with systemic lupus erythematosus, where a positive C.F.T. was common, but was invariably present in high titres in primary biliary cirrhosis patients (Walker et al., 1965).

Organ-specific thyroid and gastric antibodies in pulmonary fibrosis patients were not significantly increased above controls but were of higher titres, and the results are similar to those in rheumatoid arthritis (Buchanan et al., 1961) and certain forms of cirrhosis. Recent confirmation of a greater incidence of subclinical thyroiditis in rheumatoid arthritis has also been obtained in post-mortem histological studies (Becker et al., 1963). Specific lung antibodies were not detected. Such antibodies have been reported in experimental animals (see review by Burrell, 1963), but C.F.T. studies in various lung diseases in man suggest that some antibodies detected (Hennes et al., 1962 ; Balchum et al., 1963) may have been non-organ-specific, although Thomas (1964) found lung specific reactions in patients with primary atypical pneumonia.

Tomasi et al. (1962) suggested that pulmonary involvement in patients with high-titre rheumatoid factors might be due to deposition of antigen-antibody complexes in the pulmonary capillaries. It is known that such complexes can give rise to fibrosing inflammatory responses at other sites-for instance, in the renal glomeruli (see Dixon, 1963), the skin in lupus erythematosus (Burham et al., 1963 ; Cormane, 1964), and possibly in the thyroid gland, where the fibrous variant of Hashimoto's disease is associated with particularly high titres of thyroglobulin precipitins. We failed to find fixed antibodies in two lung biopsies either with anti- $\gamma$-globulin or anticomplement conjugates; but this does not disprove the theory, since complexes are known to be removed by macrophages, and the lesions may represent tissue reactions to previous immunological damage caused by antigen-antibody complexes, possibly mediated by the release of pharmacologically active substances in the lung.

\section{Summary}

Auto-antibody studies were performed in 48 patients with interstitial pulmonary fibrosis, of whom 14 also had rheumatoid arthritis. Positive results in one or more tests were obtained in 32, most of the antibodies being of non-organ-specific nature.

Rheumatoid factors were present in $49 \%$ of cases, including all the patients with arthritis but also in 11 out of 34 cases without joint manifestations, and in these the differential agglutination titre was more often positive than the latex F II test.

Antinuclear factors were detected in $28 \%$ as compared with $4 \%$ of matched controls, and two-thirds of positive reactors had negative D.A.T.

Non-organ-specific complement-fixing antibodies were found in $19 \%$ of patients (controls $2 \%$ ), all of whom also had antinuclear factors or rheumatøid factors.

Auto-antibodies specific to lung could not be detected by immunofluorescent techniques in the patients' serum, nor could fixed antigen-antibody complexes be demonstrated in biopsies on two cases of interstitial pulmonary fibrosis.

The incidence of thyroid and gastric parietal-cell antibodies was not significantly different from that of controls.

We would like to thank the physicians of the Brompton Hospital for full access to the patients, and Professor J. G. Scadding for allowing us to study many cases under his care, for his unfailing support throughout this work, and for his helpful criticisms of the manuscript. We are grateful to Dr. Keith Jefferson, who kindly helped with the radiographic assessment, and to Mr. P. M. Payne, who undertook the statistical analysis of Fig. 1. We thank Mr. Keith Jobbings and Mr. K. G. Couchman for their technical assistance. The autoimmunity laboratory at the Middlesex Hospital is supported by grants from the Medical Research Council, the British Empire Cancer Campaign, and the Vaughan Hudson Clinical Research Fund.

\section{REFERENCES}

American Rheumatism Association (1959). f. Amer. med. Ass., 171, 1205.

Andrews, E. C. (1957). Bull. fohns Hopk. Hosp., 100, 28.

Balchum, O. J., Buckley, R., Levy, S., Bertolino, J., Swann, H., and Hall, J. (1963). Arch. environm. Hith, 8, 132

Ball, J., and Lawrence, J. S. (1961). Ann. rheum. Dis., 20, 235. Becker, K. L., Titus, J. L., Woolner, L. B., and Ferguson, R. H. (1963).
Proc. Mayo Clin., 38, 125 . 
Bono, G., Castello, D., and Crosato, M. (1963). Minerva pediat., 15, 1097.

Buchanan, W. W., Crooks, J., Alexander, W. D., Koutras, D. A., Wayne, E. J., and Gray, K. G. (1961) Lancet, 1, 245.

Bunim, J. J. (1961). Ann. rheum. Dis., 20, 1.

Burnham, T. K., Neblett, T. R., and Fine, G. (1963). 7. invest. Derm., 41, 451.

Burrell, R. G. (1963). Amer. Rev. resp. Dis., 87, 389.

Caplan, A. (1953). Thorax, 8, 29.

Payne, R. B., and Withey, J. L. (1962). Ibid., 17, 205.

Cormane, R. H. (1964). Lancet, 1, 534.

Dixon, F. J. (1963). Harvey Lect., 58, 21.

Doniach, D., and Roitt, I. M. (1963). In Clinical Aspects of Immunology, edited by P. H. G. Gell and R. R. A. Coombs. Blackwell, Oxford.

Dresner, E., and Trombly, P. (1959). New Engl. F. Med., 261, 981.

Edwards, J. E., and Burchell, H. B. (1951). Arch. intern. Med., 87, 372 .

Ellman, P., and Ball, R. E. (1948). Brit. med. Y., 2, 816.

Faber, V., Elling, P., Norup, G., Mansa, B., and Nissen, N. I. (1964). Lancet, 2, 344.

Forbes, I. J. (1958). Aust. Ann. Med., 7, 205.

Franklin, E. C. Zucker-Franklin, D., and McEwen, C. (1959). Arch. interamer. Rheum. (Rio de, .), $2,250$.

Geld, H. van der, Feltkamp, T. E. W., Loghem, J. J. van., Oosterhuis, H. J. G. H., and Biemond, A. (1963). Lancet, 2, 373 .

Hamman, L., and Rich, A. R. (1944). Bull. fohns Hopk. Hosp., 74, 117. Hayman, L. D., and Hunt, R. E. (1952). Dis. Chest, 21, 691.

Hennes, A. R., Moore, M. Z., Carpenter, R. L., and Hammarsten, J. F. (1961). Amer. Rev. resp. Dis., 83, 354.
Heppleston, A. G. (1956). Thorax, 11, 77.

Hijmans, W., Doniach, D., Roitt, I. M., and Holborow, E. J. (1961). Brit. med. 7., 2, 909.

Hyun, B. H., Diggs, C. L., and Toone, E. C. (1962). Dis. Chest, 42, 449 .

Israel, H. L. (1953). Amer. 7. med. Sci., 226, 387.

Livingstone, J. L., Lewis, J. G., Reid, L., and Jefferson, K. E. (1964). Quart. 7. Med., 33, 71 .

Mackay, I. R., and Burnet, McF. (1963), Autoimmune Diseases.

Thomas, Ilï.

Milgrom, F., and Witebsky, E. (1960). F. Amer. med. Ass., 174, 56

Pernis, B., Vigliani, E. G., Heuer, A., and Cavagna, G. M. (1963). Folia allerg. (Roma), 10, 396.

Price, T. M. L., and Skelton, M. O. (1956). Thorax, 11, 234.

Roitt, I. M., and Doniach, D. (1965). Scientific Basis of Medicine. In press.

Rose, H. M., Ragan, C., Pearce, E., and Lipman, M. O. (1948). Proc. Soc. exp. Biol. (N.Y..), 68, 1 .

Scadding, J. G. (1960). Brit.. med. f., 1, 443.

(1964). Ibid., 2, 686.

Singer, J. M., and Plotz, C. M. (1956). Amer. F. Med., 21, 888.

Taybor, K. B., Roitt, I. M., Doniach, D., Couchman, K. G., and Shapland, C. (1962). Brit. med. 7., 2, 1347 .

Thomas, L. (1964). New Engl. 7. Med., 270, 1157.

Tamasi, T. B., Fudenberg, H. H., and Finby, N. (1962). Amer. \&. Med., 33, 243.

Walker, G., Doniach, D., Roitt, I. M., and Sherlock, S. (1965). Lancet. In press.

\title{
Propranolol (Inderal) in Disturbances of Cardiac Rhythm
}

\author{
D. J. ROWLANDS,* M.B., B.SC., M.R.C.P. ; G. HOWITT,* M.D., M.R.C.P., M.R.C.P.ED. ; \\ P. MARKMAN,* M.B., M.R.C.P., M.R.C.P.ED., F.C.P.S.A.
}

Brit. med. Y., 1965, 1, 891-894

Black and Stephenson (1962) reported the results of betaadrenergic-receptor blockade in animals, using pronethalol. They found that the drug induced bradycardia and they indicated the possibility of using it in certain arrhythmias. Stock and Dale (1963) reported its use on patients with various arrhythmias. They found it useful in controlling the ventricular rate in atrial fibrillation and in the treatment of digitalisinduced arrhythmias, and they studied its effect in supraventricular tachycardias and upon various types of ectopic beat. After the production of evidence that the drug is carcinogenic to mice (Paget, 1963) the makers advised that its use should be restricted to those conditions that directly threaten life or to those patients whose life-expectation is short. The development of propranolol (Inderal), which is free from carcinogenic activity in mice (Black, Crowther, Shanks, Smith, and Dornhorst, 1964) and has a therapeutic ratio ten to twenty times greater than pronethalol, has renewed interest in the clinical application of beta-receptor blockade. The present paper reports experiences using propranolol in selected cases of atrial fibrillation, in atrial flutter and tachycardia, and in ventricular arrhythmias.

\section{Atrial Fibrillation}

Eleven patients were studied. Of these, five had rheumatic heart disease, four had thyrotoxicosis, one had mitral stenosis and thyrotoxicosis, and one had no underlying cardiac disorder. The patients with rheumatic heart disease were selected because of failure to control the ventricular rate at rest or on exercise with maximum tolerated doses of digitalis. The patient with idiopathic atrial fibrillation was studied both before and after digitalization. Those patients with thyrotoxicosis had been given digitalis to the maximum tolerated dose.

- Univeraity Department of Cardiology, Manchester Royal Infirmary.
Seven patients were studied before and during steady-state exercise on the cycle ergometer in the supine position. The patients were exercised for four minutes and the heart rate was measured during the last half-minute of exercise. The work load was kept constant for each individual patient. The propranolol was given intravenously in a standard dose of $10 \mathrm{mg}$. The resting rate after the drug was given was taken as the mean of readings at five-minute intervals between 15 and 25 minutes after the injection.

\section{Rheumatic Atrial Fibrillation}

In the six cases studied the ventricular rate was controlled better by the combination of digitalis and propranolol than by digitalis alone (Table I).

It is well recognized clinically that some patients have rapid ventricular rates which are resistant to digitalis therapy. In the presence of mitral stenosis, tachycardia reduces diastolic filling time and may reduce ventricular filling, so causing an

TABLE I.-Ventricular Rate (Per Minute) in Atrial Fibrillation at Rest

\begin{tabular}{|c|c|c|c|c|c|c|c|}
\hline \multirow{3}{*}{$\begin{array}{l}\text { Case } \\
\text { No. }\end{array}$} & & & & \multicolumn{2}{|c|}{ Rest } & \multicolumn{2}{|c|}{ Exercise } \\
\hline & \multirow{2}{*}{\multicolumn{3}{|c|}{ Diagnosis }} & Before & After & Before & After \\
\hline & & & & \multicolumn{2}{|c|}{ Propranolol } & \multicolumn{2}{|c|}{ Propranolol } \\
\hline $\begin{array}{c}1 \\
2 \\
3 \\
4 \\
5 \\
6^{*} \\
7 \\
8 \\
9 \\
10 \\
11 \dagger \\
11\end{array}$ & $\begin{array}{l}\text { Rheumatic hear } \\
\text { ", } \\
\text { ", } \\
\text { Thyrotoxicosis" } \\
\text { ", } \\
\text { Idiopathic } \\
\text { ". }\end{array}$ & $\begin{array}{l}\mathrm{t} \mathrm{di} \\
\\
\because \\
\because \\
\because \\
\therefore \\
\therefore\end{array}$ & 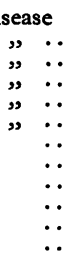 & $\begin{array}{r}117 \\
126 \\
160 \\
204 \\
108 \\
112 \\
132 \\
148 \\
96 \\
156 \\
132 \\
87\end{array}$ & $\begin{array}{r}80 \\
72 \\
96 \\
140 \\
84 \\
72 \\
84 \\
91 \\
66 \\
90 \\
93 \\
63\end{array}$ & $\begin{array}{l}174 \\
158 \\
155 \\
114 \\
189 \\
190 \\
147\end{array}$ & $\begin{array}{r}144 \\
85 \\
110 \\
81 \\
120 \\
153 \\
108\end{array}$ \\
\hline
\end{tabular}

